\title{
Tillid under COVID-19
}

\author{
Artikel 8 \\ BRIAN ARLY JACOBSEN, LENE KÜHLE OG HENRIK REINTOFT \\ CHRISTENSEN
}

ENGLISH ABSTRACT: In the article, we examine Danes' trust in the authorities during the crisis, the relationship between the high degree of trust in the authorities and compliance with the authorities' advice to avoid the spread of infection, and how a growing distrust of society can have consequences for the cohesion in the society, including increasing polarization. The general trust in other people is high in Denmark, and our study shows that trust in the authorities has grown during the pandemic. However, the study shows incipient signs of polarized trust in the population. Religion does not seem to play a role in this development, which instead seems to be associated with material and social insecurity. Research in trust generally indicates that the basis for the strong cohesion that Danish society has shown for decades is precisely trust. If the material and social consequences of the pandemic create fertile ground for change in the level of trust, it can help to create a value setback for the norms that create cohesion in society.

DANSK RESUMÉ: I artiklen undersøger vi danskernes tillid til myndighederne under krisen, relationen mellem den høje grad af tillid til myndighederne og efterlevelse af myndighedernes råd for at undgå spredning af smitte, samt hvordan en stigende mistillid til samfundet kan have konsekvenser for samfundets sammenhængskraft blandt andet $i$ form af stigende polarisering. Den generelle tillid til andre mennesker er høj $i$ Danmark, og vores undersøgelse viser, at mange har fäet mere tillid til myndighederne under pandemien. Undersøgelsen viser dog begyndende tegn på polariseret tillid $i$ befolkningen; men religion synes ikke at spille en rolle for denne udvikling. Det synes $i$ stedet at vxre materiel og social usikkerhed, som er årsager, og som på sigt underminerer den høje grad af tillid, det danske samfund ellers har haft. Tillidsforskning peger generelt på, at grundlaget for den stærke sammenhængskraft, som det danske samfund har vist $i$ årtier, netop er tillid. Hvis pandemiens materielle og sociale konsekvenser skaber grobund for forandring i tillidsniveauet, kan det være med til at skabe et vardimæssigt tilbageslag for de normer, som skaber sammenhængskraft $i$ samfundet.

KEY WORDS: COVID-19; religiosity; generalized trust, social cohesion; polarization 
COVID-19 pandemien er global, men har haft konsekvenser af varierende grad i forskellige lande. Mange steder gennemførte man, som i Danmark, nedlukninger; men hvert enkelt land havde sin egen version af nedlukningspolitikken: I nogle lande havde man udgangsforbud, i nogle lande - som i Danmark - fokuserede man især på nedlukning af de offentlige institutioner inklusive museer og biblioteker, mens disse i andre lande var undtaget eller hurtigt lukkede op igen. I visse lande undtog eller begrænsede man også, som vi diskuterede i artikel 4 om "COVID-19 og religion", nedlukning af religiøse institutioner. Det amerikanske Pew Research Center foretog i sommeren 2020 en undersøgelse af, hvordan befolkningen i 14 lande vurderer håndteringen af pandemien (Pew Research Institute 2020b). Ifølge denne undersøgelse er Danmark det land, hvor befolkningen har været mest tilfreds med myndighedernes håndtering. Pandemien ledte flere steder i verden til en vækst i religiøst engagement, som er blevet forstået som udtryk for en søgen efter tryghed, sikkerhed og værn mod virussen: Folk kan siges at forsøge at 'cope' ('klare den') ved at orientere sig religiøst og eksempelvis søge Gud som en hjælp og støtte ved alvorlig sygdom eller krise. Når man taler om religiøse forandringer på denne måde, er det imidlertid typisk ikke hele befolkningen, der bliver mere eller mindre religiøs. Det er typisk ændringer i bestemte grupper, som driver udviklingen og får os til at konkludere, at der er sket religiøs forandring eller vækst. Undersøgelser fra bl.a. USA (Pew Research Institute 2020a, American Perspectives Survey 2020) peger på, at det især er blandt marginaliserede grupper, at krisen synes at have ledt til en øget religiøs interesse. Der findes en undersøgelse, som dokumenterer en global vækst i internetsøgninger på bøn under pandemien (Bentzon 2020); men det er værd at bemærke, at de ændrede søgemønstrene især blev registreret i Afrika og Sydamerika, det vil sige i områder, hvor mangelfulde sundhedssystemer gør folk usikre på, hvorvidt de kan få den hjælp, de behøver, hvis sygdommen rammer. Reaktionerne på en krise kan således være påvirket af den tillid, man har til, om man har adgang til et velfungerende sundhedssystem, og at politikerne og staten tager hånd om udfordringerne. Forventning om at der kan være sammenhænge mellem folks brug af religion i kriser og myndighedernes håndtering af usikkerhed, leder til en række overvejelser:

- Danskernes tillid til myndighederne under krisen er af afgørende betydning, fordi myndighederne har gennemført omfattende indgreb $i$ de fleste menneskers hverdag. Store dele af samfundet blev lukket ned i begyndelsen af marts og kun langsomt åbnet op i løbet af sommeren. Mens den generelle fornemmelse af samfundsmæssigt sammenhold var stor i foråret, blev de politiske partier over sommeren i stigende grad også uenige om regeringens håndtering, og der viste sig også i stigende grad splittelse i samfundet.

- For at fä befolkningen til at efterleve anbefalinger og retningslinjer er det vigtigt, at befolkningen har tiltro til myndighedernes analyse af situationen; men i usikre perioder er der mulighed for, at konspirationsteoretiske ideer kan få en mere central placering $i$ den offentlige debat. Vores antagelse er, at befolkninger, der $i$ højere grad end andre har stor tillid til myndighederne, vil følge myndighedernes råd for at undgå 
spredning af smitte. Derfor er det relevant at undersøge, hvor udbredte disse ideer er. Vi ved fra udlandet, og særligt USA, at en række teorier om coronavirus er i omløb, som kan betegnes som konspirationsteorier.

- Stigende mistillid til samfundet kan have konsekvenser for samfundets sammenhængskraft blandt andet i form af stigende polarisering. Da sammenhængskraften generelt opfattes som en særlig vigtig dimension i forståelse af den danske samfundsmodel, er det relevant at undersøge, hvorvidt befolkningen mener, at pandemien har konsekvenser for samfundet. Det gør vi blandt andet ved at undersøge, om man udpeger særlige grupper som årsag til smittespredning, samt om tilliden polariseres inden for tre faktorer, der har konsekvenser for socialisering og socioøkonomiske forskelle, nemlig uddannelse, indkomst og helbred.

Vores respondenter fremstår som udpræget sekulære, og vi kan ikke umiddelbart registrere en forøget religiøs interesse (se artikel 4, “COVID-19 og religion”). En forklaringsmodel kunne bygge på ideen om Danmark som et velfærds- og tillidssamfund, hvis rationale baseres på sekulære principper. Det betyder, at de offentlige, politiske argumenter for en velfærdsstat og dennes institutioner, såsom social- og sundhedsmæssig omsorg - og for de basale goders fordeling - kun kan findes i demokratiske og ikke-religiøse argumenter. ${ }^{1}$ Sammenligner vi danskerne med andre befolkninger, viser undersøgelser, at danskerne, og generelt de nordiske velfærdsstater, er blandt de lande, hvor der er mest social tillid. Social tillid er et udtryk for en generel indstilling eller holdning, og der findes en række fortolkninger af, hvordan tillid kan forstås. Det kan for det første forstås som udtryk for en generel risikokalkule vedrørende fremtidig omgang med andre mennesker baseret på for eksempel individets tidligere erfaringer med andre mennesker, deres oplevelse af kriminalitet i samfundet og deres erfaringer med myndighederne (Larsen 2011, 115-16). En anden forståelse giver udtryk for individets generelle, moralske vurdering af deres samfund og medborgere (Rothstein 2010, 19). En tredje forståelse beskrives af politolog Gert T. Svendsen (2012, 15) således: "Social tillid afviger altså her grundlæggende fra individuel tillid, fordi tilliden bliver udvidet til at omfatte mennesker, som den tillidsfulde part ikke har direkte information om". I denne forståelse understreges det, at mens tillid til ens egne sociale grupper kan være årsag til interessekonflikter og i sidste ende sociale spændinger i samfundet som helhed, så er social tillid et udtryk for, at man som samfundsborger deler et bånd med alle andre borgere i samfundet (ibid.).

Så vidt vi ved, er der ingen komparative undersøgelser, der har undersøgt, om befolkninger i lande med stor tillid i højere grad end andre følger myndighedernes råd om begrænsning af smitte. Men en norsk undersøgelse, der blev udført i den før-

1 Et stort studie af religion i de nordiske velfærdstater argumenterer for, at den sekulære fortælling om disse lande er for reduktiv og at det er nødvendigt at se samfundene som meget mere komplekse, herunder også at se de religiøse organisationer som en del af de nordiske civilsamfund (Furseth 2018). 
ste fase af pandemien, viser, at nordmændenes tillid til myndighederne i første omgang var vigtig for, hvordan de reagerede på coronarestriktionerne. De, der har den største tillid til myndighederne, følger flere af coronarådene end dem med lav tillid. Det, der betyder mest, hvis en person følger rådene, er imidlertid, hvor bekymret denne er for at blive smittet (Wollebæk et al. 2020).

Når det gælder tillid til offentlige institutioner, scorer Danmark også højt i den internationale værdiundersøgelse, hvor 78 procent af danskerne svarer, at de har 'meget stor' eller 'ret stor' tillid til 'sundhedssystemet', mens svarene for eksempel i et land som Italien ligger noget lavere med 63 procent for samme spørgsmål. I Italien stoler næsten 4 ud af 10 personer altså kun lidt eller slet ikke på sundhedssystemet et tankevækkende resultat for de italienske myndigheder set $i$ lyset af betydningen af bekæmpelse af epidemien med nødvendige råd, reguleringer og behandlinger. Den samme lavere tillid blandt italienere gælder alle offentlige institutioner. Hvis folk ikke stoler på institutionerne, er det sværere at få dem til at følge landets love. I pandemiens tilfælde handler det om reguleringer vedrørende bekæmpelse af COVID-19. Internationale spørgeskemaundersøgelser, som ovennævnte, peger på, at Danmark, sammen med de øvrige skandinaviske lande, har den højeste grad af social tillid i verden. Høj social tillid til offentlige institutioner afspejler blandt andet, at risikoen for ikke at få indfriet sine forventninger til hjælp i tilfælde af social nød eller sygdom er lav, og det fremmer det uformelle samarbejde i befolkningen med eksempelvis at løse problemer i forbindelse med en pandemi. Et eksempel kunne være et initiativ som fællessang med Phillip Faber, der i løbet af pandemien er kommet til at fungere som en illustration af det uformelle samarbejde i befolkningen, selvom fællessangen jo ikke er spontan, men netop igangsat af Danmarks Radio. Ideen med fællessangen var, at den både udtrykte, men også styrkede en solidaritet, hvor folks fællesskabsopbyggende sang i deres stuer og fra deres altaner. Her kan alle være med, og pludselig kan den, der var ensom før, sidde og føle sig inkluderet i et stort nationalt fællesskab.

Ifølge Gert T. Svendsen $(2012,18)$ lever vi 'endnu' i tillidssamfundet Danmark. Med ordet 'endnu' refererer Svendsen til, at tillidssamfund ikke skyldes en naturlov. Det skyldes derimod, at den danske befolkning vælger at støtte en samfundsmodel, der genererer, men også forudsætter en høj grad af social tillid. Spørgsmålet er derfor om den danske befolkning fortsætter med at være tillidsværdige over for hinanden også og måske især i en pandemitid. Tillid er forbundet med mange andre variable. Vi vil have et særligt fokus på, hvorvidt der er en sammenhæng med religiøsitet. Vi trækker i overvejende grad på resultaterne fra den første indsamlingsrunde i maj; men vi har i nogle tilfælde også inddraget svarene fra dataindsamlingen i oktober.

\section{Tillid til andre og til myndighederne}

Vi har stillet spørgsmålet 'Mener du generelt, at de fleste mennesker er til at stole på eller mener du, at man ikke kan være for forsigtig, når man har med mennesker at gøre?' Dette spørgsmål stammer fra den internationale værdiundersøgelse, og vi kan 
derfor sammenligne de resultater vi gengav ovenfor med resultaterne fra vores undersøgelse. ${ }^{2}$

Tabel 8.1. Mener du generelt, at de fleste mennesker er til at stole på eller mener du, at man ikke kan være for forsigtig, når man har med mennesker at gøre? Procent.

\begin{tabular}{llll} 
& EVS 2017* & Maj & Oktober \\
\hline De fleste mennesker er til at stole på & 77 & 70 & 64 \\
Man kan ikke være for forsigtig & 23 & 30 & 36 \\
\hline $\mathrm{N}$ & 3344 & 1403 & 1169
\end{tabular}

${ }^{*}$ EVS, Den Europæiske Værdiundersøgelse.

Tabellen viser, at den andel, der mener, at de fleste mennesker er til at stole på, ligger lidt lavere i vores undersøgelse sammenlignet med Værdiundersøgelsen. Da vores undersøgelse er en panelundersøgelse, er det imidlertid muligt at sammenligne ændringen i svarene fra maj til oktober, og her er der sket et signifikant fald på seks procentpoint.

Pew Research Center stillede i løbet af sommeren spørgsmål til befolkningen i 14 lande om, hvorvidt svarpersonerne mente, at krisen havde forenet samfundet. Danmark lå i top, idet 72 procent af de adspurgte var enige $i$, at krisen havde forenet danskerne, mens det tilsvarende gjaldt for 58 procent af svenskerne, 39 procent af tyskerne og 18 procent af amerikanerne (Pew Research 2020b). I vores undersøgelser er der ikke nogen signifikant sammenhæng mellem hverken religiøsitet eller spiritualitet og holdningen til om, de fleste mennesker er til at stole på (artikel 4, "COVID19 og religion"). Men det overordnede resultat, det vil sige faldet i andelen der angiver, at 'de fleste mennesker er til at stole på', er interessant. Med udgangspunkt i en sammenligning af resultaterne fra de to indsamlingsrunder kan man spørge, om krisen bidrager til at nedbryde den samfundsmæssige tillid.

\section{Tillid til myndighederne}

Under COVID-19 pandemien har regeringer verden over skulle tage nogle beslutninger med afgørende betydning for de respektive landes befolkninger. Som nævnt ovenfor viste Pew Research Centers undersøgelse, at støtten til regeringen blandt befolkningen i Danmark er større, end den støtte andre landes borgere udviser til deres ledere (foretaget 10. juni - 3. august 2020). En undersøgelse foretaget af det danske HOPE-projekt, som sammenligner Danmark med Storbritannien, Tyskland, Frankrig, Sverige, Italien Holland og USA, er nået frem til det samme resultat (Jørgensen et al. 2020). Den generelle tilslutning til regeringens linje i en lang række lande, som har

2 Selvom det er samme spørgsmål som i Værdiundersøgelsen, kan der være problemer med at sammenligne direkte med resultaterne fra Værdiundersøgelsen, idet indsamlingsmetoderne varierer. Det kan man læse mere om i metodeappendikset. 
håndteret pandemien ganske forskelligt, er af nogle blevet forklaret som en rally effect, det vil sige som en pludselig, betydelig øget støtte i lyset af dramatiske begivenheder (vi kender denne statsmandseffekt fra terrorangreb, det at gå i krig, eller store naturkatastrofer), og ofte med følelsesmæssig frem for rationel baggrund (Reeskens et al. $2020,11)$. At store dele af befolkningen samler sig bag regeringen som en reaktion på en pludselig opstået krise, synes altså at have et særligt stort omfang i Danmark uanset om årsagen er emotionel eller rationel - og kan måske ses som udtryk for en særlig dansk tillidskultur, hvor også tilliden til myndighederne og måske også politikerne er stor. Det er på den måde indlysende, at spørgsmålet om tillid har været centralt i COVID-19-krisen. En betydelig del af vores respondenter angiver (i indsamlingen i maj), at tilliden til myndighederne på ingen måde er blevet undergravet af krisen. Tværtimod er der noget, der tyder på, at en del af danskerne føler, at de har fået større tillid til myndigheder og autoriteter i epidemiens første fase. 61 procent svarer, at de er enige (noget enige, enige og stærkt enige) i udsagnet, at de har følt sig mere tillidsfulde over for myndighederne siden corona-virussen kom til Danmark (Tabel 8.2). Denne rally effect er ikke uindskrænket. Selvom befolkningen generelt har bakket op om regering og myndigheder, er der dog signifikante forskelle mellem vælgerne i henholdsvis rød og blå blok. Tillid over for myndigheder og autoriteter er især steget hos dem, der angiver, at de stemmer på rød blok.

Tabel 8.2. Siden coronavirus kom til Danmark har jeg følt mig mere tillidsfuld over for myndigheder og autoriteter.

\begin{tabular}{lcccc} 
& Rød blok & Blåblok & Total & $N$ \\
\hline Stærkt uenig & 4 & 14 & 9 & 115 \\
Uenig & 9 & 17 & 13 & 175 \\
Noget uenig & 13 & 22 & 17 & 226 \\
Noget enig & 38 & 30 & 35 & 465 \\
Enig & 28 & 16 & 21 & 286 \\
Stærkt enig & 7 & 2 & 5 & 63 \\
\hline Total & 100 & 100 & 100 & 1331 \\
\hline$\chi^{2}=p<0,001 ; \gamma=-0,396$. & & &
\end{tabular}

Forskellen mellem blokkene afspejler givet en politisk bestemt holdning til regeringen, hvor rød bloks vælgere logisk har en signifikant højere grad af tillid til en socialdemokratisk regering, men næsten halvdelen af de respondenter, der angiver at stemme på et parti i blå blok, er også blevet mere tillidsfulde over for myndigheder og autoriteter. Overordnet er der også en overvældende andel (ca. 80 procent), der mener, at løsningen på krisen er 'At følge eksperternes råd og vejledning'. 
Vi har derudover undersøgt, om tilliden til myndighederne varierer i forhold til religiøsitet og spiritualitet. Der er ingen signifikante forskelle. Det vil sige, at tilliden til myndighederne ikke afhænger af, om folk er religiøse, spirituelle eller ikke-troende. Det indikerer umiddelbart, at det danske samfund ikke er præget af brudflader på grund af manglende tillid til myndighederne forårsaget af religiøse eller spirituelle positioner.

Tabel 8.3. Mere tillid til myndigheder og eksperter i forhold til religiøsitet, procent

\begin{tabular}{llllll} 
& $\begin{array}{l}\text { Mindst } \\
\text { religiøse } \\
n=689\end{array}$ & $\begin{array}{l}\text { Mellem- } \\
\text { gruppe } n=322\end{array}$ & $\begin{array}{l}\text { Mest religiøse } \\
n=96\end{array}$ & Total & $n$ \\
\hline Stærkt uenig & 10 & 7 & 9 & 9 & 96 \\
Uenig & 12 & 11 & 17 & 12 & 135 \\
Noget uenig & 18 & 16 & 16 & 17 & 189 \\
Noget enig & 36 & 34 & 32 & 35 & 392 \\
Enig & 20 & 25 & 22 & 22 & 54 \\
Stærkt enig & 4 & 7 & 4 & 5 & 1107 \\
\hline Total & 100 & 100 & 100 & 100 & \\
\hline
\end{tabular}

$\gamma=0,08, p=0,066$

Der er således ikke umiddelbart noget, der tyder på, at religiøse synspunkter eller positioner står i modsætning til myndighedernes autoritet. Det betyder også, at religiøsitet ikke umiddelbart er en relevant variabel i forhold til forståelsen af tillid. Men der er andre måder at tilgå spørgsmålet om tillid på.

\section{Konspiration og religion}

I løbet af COVID-19 krisen er der kommet mere fokus på, at der især i USA, og i meget mindre omfang i Danmark, er grupper, der aktivt har bekæmpet forståelsen af COVID-19 som en alvorlig sundheds- og samfundsmæssig udfordring. I mediernes dækning af både pandemien og præsidentvalget i USA i 2020 har der især været fokus på eksistensen af den såkaldte QAnon-bevægelse, en højreorienteret bevægelse, der hævder, at en fraktion af Satan-tilbedende pædofile har etableret en global børne-sexhandelsring og planlagt valgsvindel mod den forrige amerikanske præsident Donald Trump. ${ }^{3}$ Mange tilhængere af QAnon hævder, at COVID-19 er blevet brugt af Kina og/eller Det Demokratiske Parti i USA for at stoppe genvalget af Trump (Sternisko og

Kevin Roose, “What Is QAnon, the Viral Pro-Trump Conspiracy Theory?". The New York Times, 28. august, 2020. 
van Bavel 2020). Teorier som QAnons er forbundet med spørgsmålet om den troværdighed, som regeringen og myndighedernes udlægninger af virkeligheden har. Ifølge en undersøgelse foretaget af Survey Center on American Life angav 87 procent af de adspurgte, at den amerikanske regering ofte eller undertiden tilbageholdt vigtige oplysninger fra offentligheden. Dette er jo et ganske høj tal. Mere specifikt angav 22 procent, at de mente, at COVID-19 var produceret af Kina som en del af deres biologiske våbenprogram (Cox og Halpin 2020). Det er en opfattelse, der kan forbindes med konspirationsteorier, som siden marts er vokset betragteligt i antal følgere og som også har spredt sig til Europa. ${ }^{4}$

Idéhistorikeren Mikkel Thorup peger på, at konspirationsteorier (også) er magtkritik. Han argumenterer for, at "konspirationsteorier abonnerer på den væsentlige kritiske indsigt, at vi ikke kan forudsætte korrespondens mellem magtens fremtrædelse og dens virkelighed, mellem det officielle og det reelle" (Thorup 2014, 157). Under nedlukningens forskellige faser, og især med stigende styrke fra september måned, har Danmark, som andre lande i bl.a. Europa, set en stigning i grupper, der sætter spørgsmålstegn ved myndighedernes officielle budskab om COVID-19 og epidemiens konsekvenser og deraf følgende reguleringer, om end disse grupper stadig udgør et mindre antal. I Danmark er der således bevægelser repræsenteret, som udover at gøre sig bemærket på for eksempel Facebook-grupperne Men In Black, Denmark (ca. 19.700 følgere pr. 12. februar 2021), Free Observer (ca. 6.200 følgere pr. 12. februar 2021) og Danmark Vågner (ca. 8.500 følgere pr. 12. februar 2021), der forfægter teorier i stil med QAnons, også har arrangeret demonstrationer mod håndteringen af corona $\mathrm{i}$ Danmark. ${ }^{5}$

Også i forhold til spiritualitet er der kommet fokus på konspirationsteorier, fordi der i nogle miljøer i forvejen er grobund for skepsis over for 'officielle fortolkninger'. Religionssociologen Anna Rusmann har vist, hvordan en stor del af vaccinationsmodstanderne er spirituelle, og at modstanden kan forklares ved, at deres holistiske syn på kroppen som helhed ikke stemmer overens med vaccinationens logik (Rusmann 2017). Pandemien synes, at have givet et rygstød til en organiseret protest imod "en grisk og skruppelløs medicinalindustri, der har misbrugt et totalt korrupt WHO til at vildlede alverdens regeringer", som for eksempel Organisationen til Oplysning om Corona udtrykker det. ${ }^{6}$ Men sammenblandingen af konspirationsteorier og spiritualitet er ikke en ny ting. Allerede i 2011 beskrev religionsforskerne Charlotte Ward og David Voas således fremkomsten af en politico-spiritual filosofi, som forener en traditionel konspirationsteori med New Age ideer. Med en kombination af begreberne conspiracy og spirituality kaldes dette af Ward og Voas for conspirituality. I tilfældet QAnon er det dog ikke så meget New Age, som dominerer konspirationsteorien, men en blanding af kristne evangelister og andre svært identificerbare trosforhold, som

4 France 24, "QAnon conspiracies go global in pandemic 'perfect storm", AFP 6. oktober, 2020.

5 Se for eksempel Line Tolstrup Holm, “De oprørske og skeptiske vokser i antal: Jeg vil gerne vriste coronakritikken fri af sølvpapirshattenes domæne", Berlingske, 17. oktober 2020, og Alexander Sjöberg, "Men In Black håber at blive en folkelig bevægelse. Lørdagens demonstration i København viste, at den udvikling lader til at være i gang", Politiken, 7. februar 2021.

6 Se www.facebook.com/OplysningomCorona/. Organisationens formand er lægen Søren Ventegodt. 
dominerer konspirationsteorien. For at undersøge eksistensen af konspirationsteorier har vi spurgt, 'hvorvidt man tror at corona er udviklet som led i en hemmelig plan'.

Tabel 8.4. Coronavirus er udviklet som led i en hemmelig plan blandt spirituelle, maj- og oktoberundersøgelserne (procent).

\begin{tabular}{|c|c|c|c|c|}
\hline Maj & $\begin{array}{l}\text { Ikke-spirituelle, } \\
n=1176\end{array}$ & $\begin{array}{l}\text { Spirituelle, } \\
n=198\end{array}$ & $\begin{array}{l}\text { Total, } \\
n=1374\end{array}$ & $n$ \\
\hline Stærkt uenig & 82 & 70 & 80 & 1098 \\
\hline Uenig & 9 & 9 & 9 & 124 \\
\hline Noget uenig & 2 & 8 & 3 & 44 \\
\hline Noget enig & 4 & 7 & 4 & 56 \\
\hline Enig & 2 & 4 & 3 & 34 \\
\hline Stærkt enig & 1 & 3 & 2 & 20 \\
\hline Total & 100 & 100 & 100 & 1374 \\
\hline \multicolumn{5}{|l|}{$\gamma=0,30 p .<.001$} \\
\hline Oktober & $\begin{array}{l}\text { Ikke-spirituelle, } \\
n=964 \text {. }\end{array}$ & $\begin{array}{l}\text { Spirituelle, } \\
n=166\end{array}$ & $\begin{array}{l}\text { Total, } \\
n=1130\end{array}$ & $n$ \\
\hline Stærkt uenig & 66 & 57 & 64 & 728 \\
\hline Uenig & 13 & 19 & 14 & 155 \\
\hline Noget uenig & 7 & 10 & 8 & 87 \\
\hline Noget enig & 8 & 9 & 8 & 89 \\
\hline Enig & 3 & 2 & 3 & 36 \\
\hline Stærkt enig & 3 & 2 & 3 & 35 \\
\hline Total & 100 & 100 & 100 & 1130 \\
\hline
\end{tabular}

$\gamma=0,11 p .>.116$

Tabellen viser, at der i maj overordnet set var 8 procent, der var helt eller delvist enige $i$ at virussen er udviklet som led i en hemmelig plan. I oktober var tallet steget til 14 procent. Men er dette udtryk for conspiritualitet? Det er ikke helt entydigt at slutte fra vores resultater, men blandt dem der er spirituelle, er der signifikant færre, der er helt uenige (82 procent versus 70 procent i maj og 57 procent versus 66 procent i oktober) $i$, at corona er udviklet som led i en hemmelig plan. De to undersøgelser viser forskellige resultater for gruppen af uenige. Mens der blandt dem, der blot er uenige, ses en lignende tendens i maj-undersøgelsen (ca. 9 procent for både spirituelle og ikke-spirituelle, se Tabel 8.4), ses den modsatte tendens i oktober-undersøgelsen (19 procent blandt de spirituelle over for 13 procent blandt de ikke-spirituelle). De to modsatrettede resultater betyder, at der i den samlede analyse kun viser sig en beskeden, og ikke signifikant, sammenhæng for oktober-undersøgelen $(\gamma=0,11 ; p<.116)$. Vi kan 
altså ikke spore en kon-spirituel tendens i materialet her. Dette er dog ikke tilfældet for maj-undersøgelsen, hvor der er en moderat positiv sammenhæng $(\gamma=0,3 ; p .=.001)$. Uanset, viser de to undersøgelser en udvikling, hvor antallet af stærkt uenige og uenige i udsagnet 'Coronavirus er udviklet som led i en hemmelig plan', er faldet fra maj til oktober fra 89 procent til 78 procent for alle. Faldet kan være et udtryk for, at der er flere danskere, som sætter spørgsmålstegn ved eksperters forklaringer på COVID-19, som blandt andet er kommet til udtryk i de tidligere omtalte demonstrationer især uden for Christiansborg samt COVID19-skeptiske grupper på fx Facebook.

Hvis vi kigger på svarene i forhold til religiøsitet, fremstår et komplekst mønster. Vi finder således en sammenhæng, når vi ser på svarene fra de mest og mindst religiøse respondenter, hvor de mest religiøse i mindre grad er uenige i udsagnet. De mest religiøse er ikke særligt tilbøjelige til at støtte udsagnet om en hemmelig plan, men de afviser ikke påstanden så entydigt som de mindst religiøse. Overordnet set er der statistisk tale om en relativ tydelig sammenhæng.

Tabel 8.5. Coronavirus er udviklet som led i en hemmelig plan blandt religiøse.

\begin{tabular}{|c|c|c|c|c|c|}
\hline & $\begin{array}{l}\text { Mindst } \\
\text { religiøse, } \\
n=583\end{array}$ & $\begin{array}{l}\text { Mellem- } \\
\text { gruppe } n=270\end{array}$ & $\begin{array}{l}\text { Mest religiøse, } \\
n=80\end{array}$ & Total & $n$ \\
\hline Stærkt uenig & 72 & 56 & 49 & 65 & 607 \\
\hline Uenig & 13 & 13 & 21 & 14 & 127 \\
\hline Noget uenig & 6 & 10 & 9 & 7 & 68 \\
\hline Noget enig & 6 & 10 & 6 & 7 & 69 \\
\hline Enig & 2 & 5 & 6 & 3 & 31 \\
\hline Stærkt enig & 2 & 6 & 9 & 3 & 31 \\
\hline Total & 100 & 100 & 100 & 100 & 933 \\
\hline
\end{tabular}

$\gamma=0,31 p<.001$

\section{Trues samfundets sammenhængskraft af Corona-krisen?}

Selvom det danske tillidssamfund umiddelbart synes at være gået forholdsvis uskadt gennem krisen, så er dette ikke nødvendigvis udtryk for, at det ikke har været udfordret under krisen. Det er nemlig også muligt at finde støtte til en anden fortælling end den om tilliden til medborgere og myndighederne, for krisen har haft konsekvenser for vores sundhed, vores økonomi og med vores omgang med hinanden. Det er derfor værd at undersøge, om krisen også er gået ud over den sammenhængskraft, Danmark ellers ofte beskrives med. Så selvom der er støtte til historien om, at vi har tillid 
til hinanden og til myndighederne, så der er også et andet perspektiv på den fortælling. Denne fortælling bekræfter til dels Morten Frederiksen og Jonas Toubøls hypotese om øget polariseret tillid blandt visse segmenter af danskerne i det seneste årti (Frederiksen og Toubøl 2019). De konkluderer på baggrund af analyse af Værdiundersøgelsen fra 1981 til 2017, at tre faktorer spiller en rolle for en polarisering af tillidsniveauet i Danmark, nemlig uddannelse, indkomst og helbred, hvor de erhvervsuddannede og dem med kort videregående uddannelse viser et betydeligt fald i tillid. Forklaringen på udviklingen findes i den stigning i usikkerhed, risiko og modgang, som visse segmenter i det danske samfund har gennemgået mellem 2008 og 2017. Økonomisk krise (Finanskrisen fra 2008 og frem) og migrationskrise (især Flygtningekrisen i 2015) nævnes blandt de vigtigste forklaringer (ibid. 423-24). Vi vil anvende samme variabler (uddannelse, indkomst og helbred) til at undersøge, om vi kan identificere en polariseret tillid i befolkningen som følge af pandemien. Vi viser ikke en tidsmæssig udvikling, som i Frederiksen og Toubøls analyse, men viser et øjebliksbillede på tillidsniveauet i forhold til de tre variable i maj 2020.

I forhold til uddannelse kan vi, se at de kortest uddannede har mindre tillid sammenlignet med dem med længere uddannelser.

Tabel 8.11. Tillidsniveauet efter uddannelsesniveau (procent).

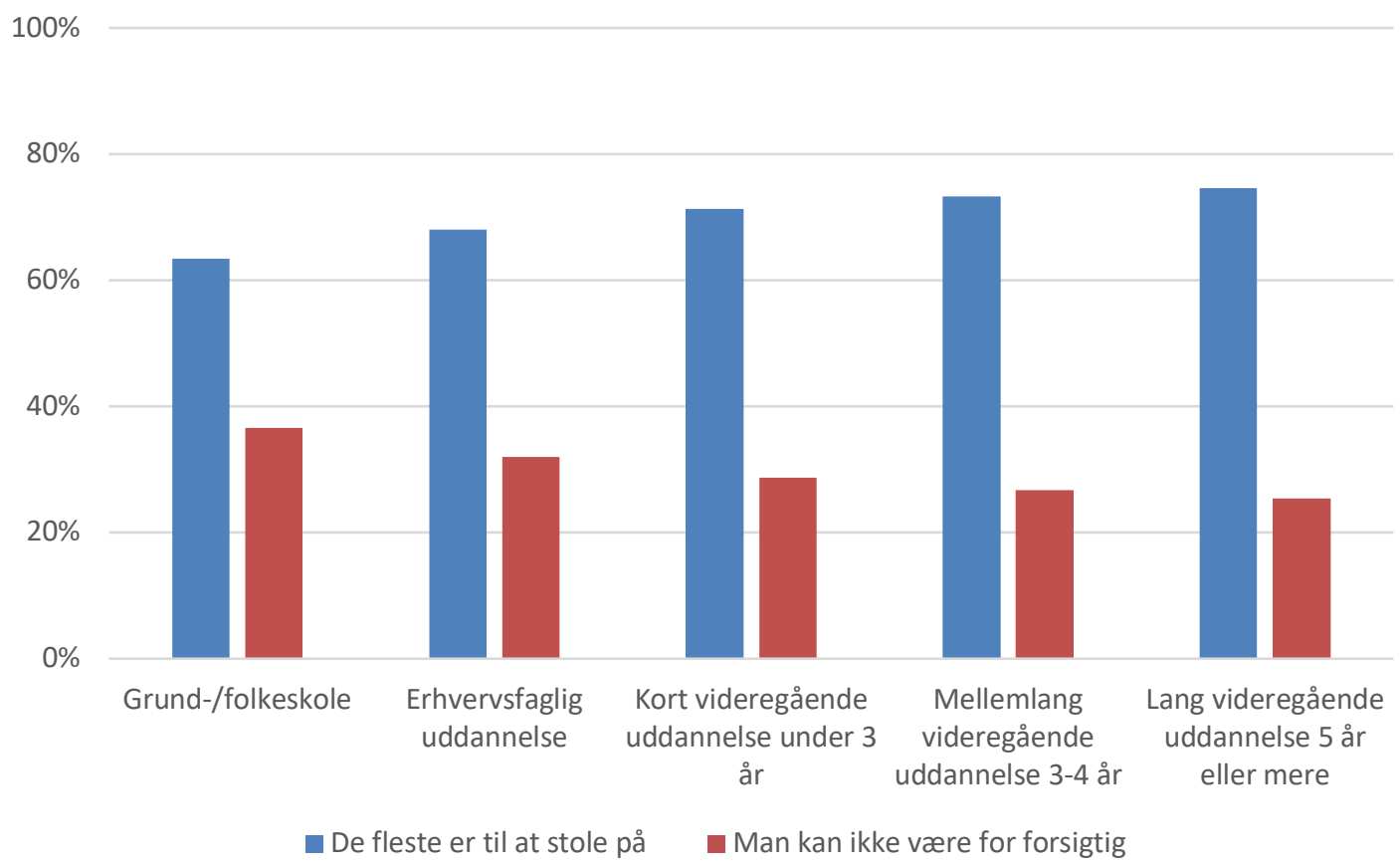

$\chi 2=p<0,002 ; \gamma=-0,124$

Tabel 8.11 viser en svag negativ sammenhæng, hvilket betyder, at jo lavere uddannelse jo færre har en generaliseret tillid til andre. Uddannelse har dermed en betydning, når det handler om tillidsniveau. Det er især grupperne med kun grundskole og erhvervsfaglig uddannelse, som trækker det gennemsnitlige niveau af generaliseret tillid ned, idet de udgør i alt 38 procent af respondenterne. 
I forhold til indkomst er den generaliserede tillid højere blandt dem, der tjener mest. Især den kvintil, der tjener mindst, viser en signifikant lavere grad af tillid end blandt de øverste kvintiler. Den viser en reel polarisering mellem grupper med middel/høje indkomster og grupper med lave indkomster. Det tyder på, ligesom i Frederiksen og Toubøls analyse, at den polariserede tillid i højere grad er knyttet til socioøkonomiske forhold end til socialisering (uddannelse) og en udvikling i normer og værdier (ibid., 407). Der er dog forskelle at bemærke i denne undersøgelse i sammenligning med Frederiksen og Toubøls analyse. I deres analyse knækker tilliden markant i 3 kvintil, mens det i denne analyse sker i de to nederste kvintiler og især i den laveste indkomstgruppe (se tabel 8.12).

Tabel 8.12. Tillidsniveauet efter disponibel husstandsindkomst (procent).

$100 \%$

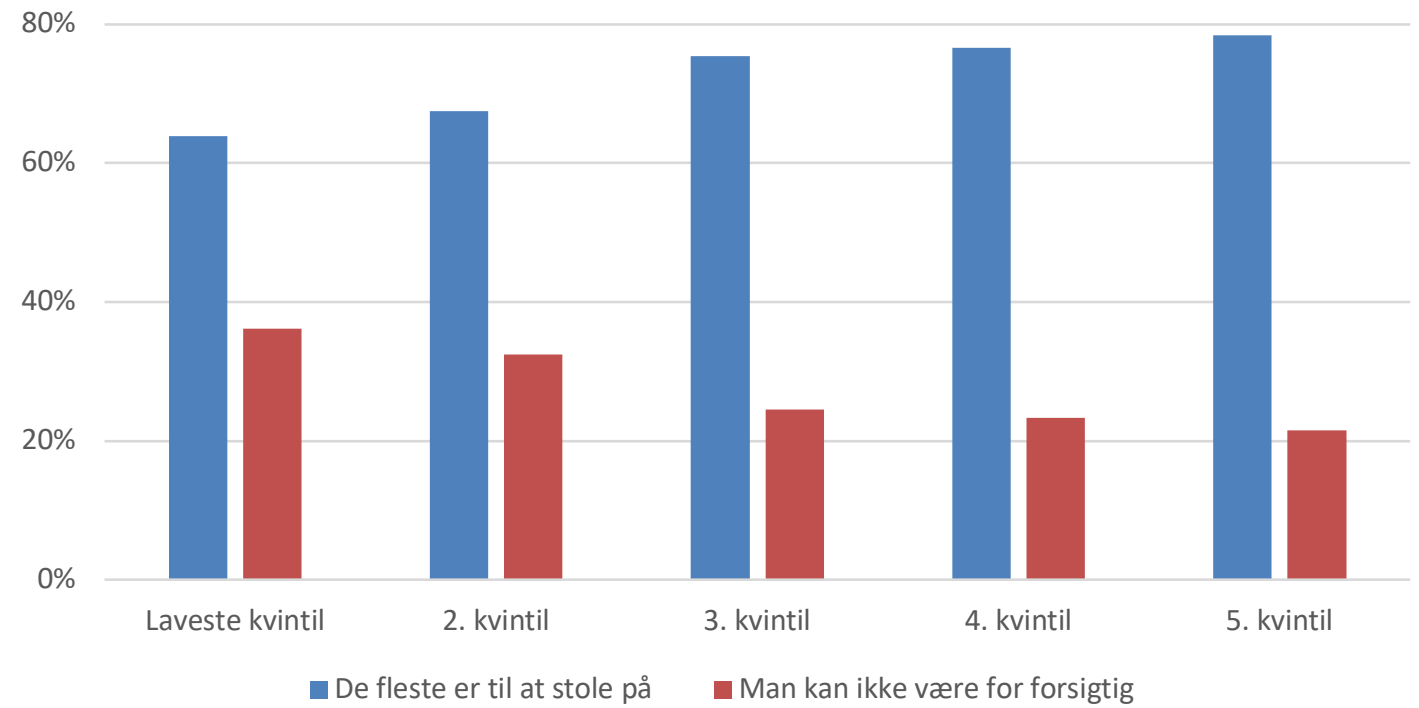

$\chi 2=p<0,001 ; \gamma=-0,194$. Fordelingen $p a ̊$ kvintiler er sammensat af den oprindelige husstandsindkomstfordeling på 11 intervaller fra 'Mindre end 100.000 kr.' til '1.000.000 kr. eller mere'. $n=1$. kvintil: 318. 2. kvintil: 271.3. kvintil: 232. 4. kvintil: 167. 5. kvintil: 167.

De to laveste indkomstgrupper udgør i denne undersøgelse 51 procent af respondenterne, hvor de samme to nederste kvintiler i Værdiundersøgelsen 2017 udgør 39 procent af respondenterne. Der er altså i vores undersøgelse en overvægt af de to laveste kvintiler, hvilket sænker den samlede generaliserede tillid i undersøgelsen.

Endelig er der selvvurderet helbred som den sidste indikator på tillid. Frederiksen og Toubøl argumenterer for, at helbred hænger sammen med tillid i den forstand, at dårligt helbred skaber usikkerhed, gør det sværere for den enkelte at deltage i sociale aktiviteter samt være aktiv på arbejdsmarkedet, på en uddannelse etc. Helbred bliver herved en ressource, som er et gode, når det handler om at håndtere usikkerhed og fastholde andre ressourcer som arbejdsindkomst, uddannelse, socialt netværk og lignende (ibid., 410). 
Tabel 8.13. Tillidsniveauet efter helbredsgrupper (procent).

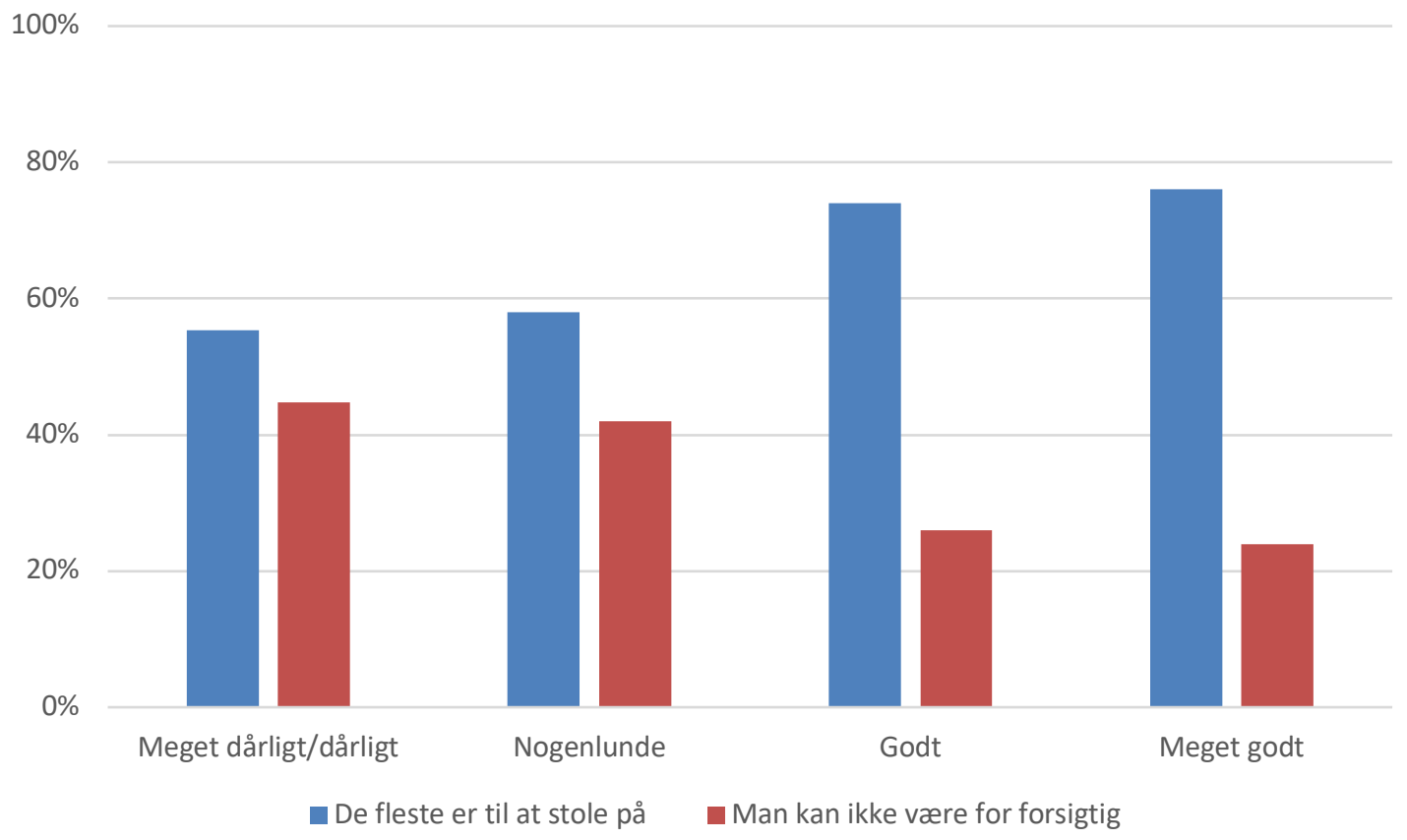

Note: $\chi 2=p<0,000 ; \gamma=-0,256$. Fordelingen på helbredsgrupper er: Meget dårligt/dårligt: 85. Nogenlunde: 286 . Godt: 627. Meget godt: 393 .

Tabel 8.13 viser, hvordan andelen af den generaliserede tillid fordeler sig i forhold til ens vurdering af eget. Ligesom for indkomst knækker den generaliserede tillid i to grupper, hvor dem, der mener, at de har et 'meget dårligt' til 'nogenlunde' helbred har en signifikant lavere generaliseret tillid end dem, der mener de har et 'godt' til 'meget godt' helbred. Det viser, at konsekvenserne af dårligt helbred har betydning for graden af tillid i samfundet, hvilket er en vigtig pointe i sig selv midt i en pandemi. Hvis andelen af personer i samfundet, som på grund af dårligt helbred oplever større usikkerhed som følge af kroniske sygdomme, COVID-19 og mulige følgevirkninger af denne sygdom ikke kan fastholde indkomst, uddannelse, socialt netværk etc., så er det en skjult følgevirkning af pandemien, som kan få samfundsmæssige konsekvenser på længere sigt for tillidssamfundet og dermed sammenhængskraften. Polariseres tilliden, kan det opfattes som et udtryk for en faldende sammenhængskraft. I lighed med Frederiksen og Toubøl finder vi også den samme mekanisme, hvor tilliden ikke er ligeligt fordelt i befolkningen, men tværtimod skævt fordelt på vigtige dimensioner som uddannelse, indkomst og helbred. Det er ikke umuligt, at pandemi-krisen kan forstærke polariseringen yderligere.

Noget af det, der kan svække tilliden og sammenhængskraften, er oplevelsen af at være i konflikt med andre mennesker. I vores undersøgelse har vi spurgt folk, om krisen har betydet, at de i stigende grad har været i konflikt eller uenig med andre mennesker.

Tabel 8.6. Siden coronakrisens start har jeg oplevet at være mere i konflikt med andre, procent. 


\begin{tabular}{|c|c|c|c|c|c|}
\hline & $\begin{array}{l}\text { Mindst } \\
\text { religiøse, } \\
n=697\end{array}$ & $\begin{array}{l}\text { Mellem- } \\
\text { gruppe } n=327\end{array}$ & $\begin{array}{l}\text { Mest religiøse, } \\
n=102\end{array}$ & Total & $n$ \\
\hline Stærkt uenig & 29 & 23 & 28 & 27 & 307 \\
\hline Uenig & 37 & 28 & 31 & 34 & 380 \\
\hline Noget uenig & 12 & 17 & 14 & 14 & 155 \\
\hline Noget enig & 16 & 20 & 16 & 17 & 191 \\
\hline Enig & 5 & 9 & 7 & 6 & 70 \\
\hline Stærkt enig & 1 & 3 & 4 & 2 & 23 \\
\hline Total & 100 & 100 & 100 & 100 & 1126 \\
\hline
\end{tabular}

Vi kan se, at det generelt ikke er tilfældet, at folk mener, de har oplevet flere konflikter. Sammenlagt svarer en fjerdedel, at de har oplevet flere konflikter; men de resterende tre fjerdedele er ikke enige i det udsagn. Ser man det i forhold til folks religiøsitet, viser det sig, at der er en lille sammenhæng, så de mest religiøse enten er mere enige $i$ at have oplevet konflikter eller mindre uenige i ikke at have oplevet konflikter sammenlignet med de ikke-religiøse. Det er særligt i gruppen mellem de mindst og de mest religiøse, at vi kan se det mønster.

Ser man på de mennesker, som vi har identificeret som spirituelle - hvoraf cirka halvdelen også indgår i mellemgruppen af religiøse - er dette resultat lidt tydeligere endnu (artikel 4, "COVID-19 og religion"). De spirituelle har oplevet at være mere i konflikt med andre end de ikke-spirituelle ( $\gamma$ 0,19 p.=.001). Da vi ikke har kendskab til niveauet af konflikter forud for krisen, kan vi ikke sige noget om antallet eller ændringen i antallet; men vi kan konkludere, at der blandt de spirituelle (og mellemreligiøse) er signifikant flere, der oplever at være i konflikt med andre under krisen end forud for krisen. En forklaring på konfliktniveauet kan hænge sammen med tesen om conspiritualitet. Forskellige teorier om spiritualitet peger alle på, at mennesket i det postmoderne samfund er blevet sin egen autoritet og ikke længere udformer sin identitet, herunder religiøse orientering, på basis af traditionen og andre autoritetskilder. Religionssociolog James Beckford har karakteriseret diverse alternative behandlingsformer som legemliggjorte udtryk for spiritualitet (Beckford 2003, 189). Et begreb som livskvalitet har indtaget en fremtrædende rolle, hvor den lettere adgang til information har skabt det kritiske individ, som ikke ukritisk tager imod sundhedsmyndigheder og andre autoriteters råd. Forklaringen er, at tiltrækningskraften blandt andet ligger $i$, at den holistiske spiritualitet kan opfattes som en modstand mod den moderne rationalisering af kroppen og følelseslivet, hvor sygdom behandles separat 
fra sine psykiske og sociale årsager (McGuire 1998, 240). Hermed er hverken forklaring eller løsning på sygdomme overladt til sundhedsvidenskaben, men til egne og ligesindedes holistiske forklaringer på sygdom og heling. Et sådan syn på corona kan være grundlag for konflikt med det store flertal af befolkningen, som fæstner tillid til sundhedsvæsenets forklaringer på pandemien samt løsninger på pleje og helbredelse. På grund af nedlukningen af samfundet, og den sociale isolation, den har medført, har vi også spurgt til, hvor forbundet man føler sig med andre mennesker. Det er et spørgsmål, som man traditionelt fortolker som en indikator for social tillid i befolkningen. Dette spørgsmål er inspireret af standardspørgsmålet fra Værdiundersøgelsen (med tilføjelsen "siden coronakrisen start"). Respondenter fortolker altid spørgsmål ind i en konkret sammenhæng, og det er derfor værd at overveje, om dette spørgsmål har forandret betydning under pandemien. Nogle kan måske forstå det som udtryk for de konkrete konsekvenser af afstandskrav, nemlig at man fysisk er mindre forbundne med andre, hvilket vil få konsekvenser for den oprindelige præmis for spørgsmålet, nemlig en indikator på sammenhængskraften, og dermed analysen af svarene.

Tabel 8.7. Siden coronakrisens start har jeg oplevet at være mere forbundet med andre, procent

\begin{tabular}{|c|c|c|c|c|c|}
\hline & $\begin{array}{l}\text { Mindst } \\
\text { religiøse, } \\
n=695\end{array}$ & $\begin{array}{l}\text { Mellem- } \\
\text { gruppe } n=329\end{array}$ & $\begin{array}{l}\text { Mest } \\
\text { religiøse, } \\
n=99\end{array}$ & Total & $n$ \\
\hline Stærkt uenig & 10 & 9 & 11 & 10 & 108 \\
\hline Uenig & 21 & 16 & 21 & 20 & 220 \\
\hline Noget uenig & 16 & 18 & 14 & 16 & 185 \\
\hline Noget enig & 25 & 26 & 19 & 25 & 279 \\
\hline Enig & 22 & 21 & 25 & 22 & 244 \\
\hline Stærkt enig & 6 & 10 & 9 & 8 & 87 \\
\hline Total & 100 & 100 & 100 & 100 & 1123 \\
\hline
\end{tabular}

For hele stikprøven kan vi se, at lidt over halvdelen (54 procent) svarer, at de i et eller andet omfang er enige i det udsagn, og det viser sig også at være jævnt fordelt i forhold til religiøsitet. Der er derfor ingen signifikant forskel på de tre grupper overordnet set. Der er flere i mellemgruppen, der er stærkt enig i, at de har oplevet at være mindre forbundet, og i den anden ende af skalaen er der færre, der er uenige i, at de har oplevet det. Ser vi igen på forskellen mellem de spirituelle og de ikke-spirituelle, kan vi se, at 57 procent af de spirituelle har oplevet at være mindre forbundet med andre mennesker, men selvom det er lidt mere end gennemsnittet, er forskellen ikke signifikant. Vi kan derfor konkludere, at lidt over halvdelen har oplevelsen af at være 
mindre forbundet med andre mennesker, og at det ikke gør en forskel om man er religiøs eller spirituel - det gælder alle.

\section{Konsekvenser for samfundet}

Vi har også spurgt til folks holdning om, hvorvidt de mener, at pandemien har konsekvenser for samfundet. 86 procent af respondenterne er enige i, at krisen har haft stærke negative konsekvenser for det danske samfunds udvikling, og peger dermed på, at fortællingen om sammenholdet, og at vi har klaret os flot gennem krisen, nemt kan komme til at skjule, at der også findes en alvorlig og mere pessimistisk fortælling. De negative konsekvenser kan både inkludere økonomiske, sociale, sundhedsmæssige og andre (ex religiøse) konsekvenser. I modsætning til forbundetheden til hinanden, er der på dette spørgsmål faktisk forskel blandt de religiøse grupper. De mere religiøse er i lidt højere grad enige $i$, at krisen har haft negative konsekvenser.

Tabel 8.8. Coronakrisen har haft stærkt negative konsekvenser for udviklingen af det danske samfund, procent.

\begin{tabular}{|c|c|c|c|c|c|}
\hline & $\begin{array}{l}\text { Mindst } \\
\text { religiøse, } \\
n=608\end{array}$ & $\begin{array}{l}\text { Mellem- } \\
\text { gruppe } n=288\end{array}$ & $\begin{array}{l}\text { Mest religiøse, } \\
n=82\end{array}$ & Total & $n$ \\
\hline Stærkt uenig & 1 & 1 & 2 & 1 & 13 \\
\hline Uenig & 4 & 3 & 4 & 4 & 39 \\
\hline Noget uenig & 7 & 6 & 5 & 7 & 64 \\
\hline Noget enig & 28 & 24 & 24 & 26 & 258 \\
\hline Enig & 34 & 30 & 33 & 33 & 319 \\
\hline Stærkt enig & 26 & 35 & 32 & 29 & 285 \\
\hline Total & 100 & 100 & 100 & 100 & 978 \\
\hline
\end{tabular}

Det samme gælder ikke når vi ser på de spirituelle. De adskiller sig ikke fra de ikkespirituelle på dette spørgsmål $(\gamma=08 p=.24)$.

\section{Syndebukke og smittespredning}

En yderligere indikation på manglende sammenhængskraft er, om man er enig i, at bestemte grupper har bidraget til smittespredning. Vi har i oktober-indsamlingen spurgt, om man mener, at religiøse grupper har bidraget til smittespredning, fordi vi fra udlandet har set eksempler på begivenheder som gudstjenester i Frankrig, der har 
været særligt smittespredende begivenheder, eller i Italien hvor kirkerne hurtigt lukkede ned i et sådant omfang, at folk tog til Schweiz for at gå i kirke eller arrangerede private gudstjenester (Ferrari 2020). Vi har derudover spurgt, om folk mener, at etniske grupper har bidraget med smittespredning. Dette spørgsmål er foranlediget af den diskussion, der opstod i løbet af sensommeren efter, at der kom fokus på smittespredning blandt etniske minoriteter - i det dansk-somaliske miljø i Aarhus og siden det dansk-pakistanske miljø i Hovedstadsregionen (Statens Serum Institut 2020). Bemærk at vi med vilje har formuleret de to spørgsmål stærkt, det vil sige med ordene 'i høj grad bidraget til smittespredning', hvormed der menes, at disse grupper i særlig grad skulle have bidraget til smittespredning.

Tabel 8.9. I Danmark har religiøse grupper i høj grad bidraget til smittespredning, procent.

\begin{tabular}{|c|c|c|c|c|c|}
\hline & $\begin{array}{l}\text { Mindst } \\
\text { religiøse, } \\
n=539\end{array}$ & $\begin{array}{l}\text { Mellem- } \\
\text { gruppe } n=267\end{array}$ & $\begin{array}{l}\text { Mest religiøse, } \\
n=76\end{array}$ & Total & $n$ \\
\hline Stærkt uenig & 4 & 5 & 24 & 6 & 55 \\
\hline Uenig & 10 & 11 & 12 & 10 & 92 \\
\hline Noget uenig & 13 & 12 & 9 & 12 & 107 \\
\hline Noget enig & 29 & 27 & 29 & 28 & 249 \\
\hline Enig & 17 & 19 & 13 & 17 & 150 \\
\hline Stærkt enig & 27 & 27 & 13 & 26 & 229 \\
\hline Total & 100 & 100 & 100 & 100 & 978 \\
\hline
\end{tabular}

Syv ud af ti (71 procent) mener, at de religiøse grupper i høj grad har været smittespredere; men måske ikke overraskende fordeler svaret på dette spørgsmål sig i forhold til, hvor religiøs man er. Jo mindre religiøs, jo mere enig er man i, at religiøse grupper i høj grad har bidraget til smittespredning.

Til gengæld er der ingen signifikant forskel på tværs af religiøst engagement i forhold til at betragte etniske grupper som smittespredere. Også her er 71 procent enige $i$, at etniske grupper har bidraget til smittespredning, og der er ikke signifikant forskel i forhold til graden af religiøsitet.

Tabel 8.10. Etniske grupper har bidraget til smittespredning, procent.

$\begin{array}{llll}\begin{array}{l}\text { Mindst } \\ \text { religiøse, }\end{array} & \text { Mellem- } & \text { Mest religiøse, } & \\ n=568 & \text { gruppe } n=276 & n=78 & \text { Total }\end{array}$




\begin{tabular}{|c|c|c|c|c|c|}
\hline Stærkt uenig & 9 & 9 & 12 & 10 & 88 \\
\hline Uenig & 11 & 7 & 15 & 10 & 96 \\
\hline Noget uenig & 10 & 8 & 8 & 9 & 85 \\
\hline Noget enig & 27 & 29 & 31 & 28 & 258 \\
\hline Enig & 17 & 20 & 13 & 17 & 160 \\
\hline Stærkt enig & 26 & 26 & 22 & 25 & 235 \\
\hline Total & 100 & 100 & 100 & 100 & 922 \\
\hline
\end{tabular}

På spørgsmålet om etniske grupper har bidraget til smittespredning, kan vi imidlertid se, at folk, der er spirituelle, adskiller sig fra den øvrige befolkning ved i langt mindre grad at være enig i udsagnet $(\gamma=-0,16, p=.005)$. Spørgsmålet om smittespredning lyder som et vidensspørgsmål; men da der ikke er viden tilgængelig om smittespredning, som kan afdække om, etniske eller religiøse grupper faktisk i særlig grad har bidraget til smittespredningen, fremstår spørgsmålene reelt som holdningsspørgsmål. Et speciale fra Aarhus Universitet har undersøgt, hvordan mediernes formidling har været med til at pålægge for eksempel den somaliske gruppe af muslimer i Aarhus skyld for øgningen af smitte i Aarhus i august 2020. Specialet konkluderer, at det er "tydeligt, at denne skyld ikke bare placeres pga. biologiske faktorer, men at der i høj grad er tale om en moralisering af somaliernes religion, deres religiøse adfærd og overbevisning, som bliver gjort til årsag til smittespredning" (Westengaard 2021, 72). Dette lægger op til, at holdningerne til smittespredningen kan ses i forlængelse af et større spørgsmål om den tillid, befolkningen har til hinanden, og dermed til spørgsmål om tillid og sammenhængskraft.

\section{Konklusion}

Overordnet kan vi konkludere, at den generelle tillid til andre mennesker stadig er høj i Danmark, og at mange har fået mere tillid til myndighederne. Vi finder dog også tegn på polariseret tillid i befolkningen; men religion synes ikke at spille en rolle for den polariserede tillid. Materiel og social usikkerhed kan på sigt underminere tillidssamfundet, som igen er grundlaget for den stærke sammenhængskraft, som det danske samfund har vist i årtier (jf. Frederiksen 2019). Det er en vigtig pointe i en pandemi, hvor både materiel og social usikkerhed udfordres i form af stigende arbejdsløshed, faldende indkomst, færre sociale aktiviteter og dermed tillidsbaseret netværksdannelse for alle i form af hjemsendelse fra arbejds- og uddannelsespladser, men især for (kronisk) syge. Pandemiens materielle og sociale konsekvenser skaber grobund for forandring i tillidsniveauet, som kan være med til at skabe et værdimæssigt tilbageslag for de normer, som skaber sammenhængskraft i samfundet. Der er 
ikke grundlag for at kæde gruppen af mennesker med ringere tillid sammen med spørgsmålet 'I Danmark har etniske grupper i høj grad bidraget til smittespredning', når det gælder de tre undersøgte faktorer (uddannelse, husstandsindkomst og helbred), da ingen af de tre variabler viser en signifikant forskel i holdningen til dette spørgsmål. Dog viser faktoren 'uddannelse' en svag negativ signifikant sammenhæng, jo mindre uddannelse jo mere enig er man i udsagnet.

Der er ikke mange, der støtter op om den konspiratoriske forestilling om en plan bag udviklingen af corona, om end der er en stigning fra maj til oktober i antallet af danskere, der er enige i udsagnet 'Coronavirus er udviklet som led i en hemmelig plan'. Der er generelt en høj grad at tiltro til videnskabens evne til at bekæmpe COVID-19 og politikernes og myndighedernes evne til at håndtere krisen. Det er dog ikke en tillid, der er konstant. Der er begyndende ridser i lakken. Der er en skepticisme, der truer sammenhængskraften som på sigt kan få konsekvenser. Omtrent en fjerdedel oplever at have flere konflikter med andre som følge af krisen, halvdelen føler sig mindre forbundet med andre, og over tre fjerdedele mener, at krisen har haft stærkt negative konsekvenser for samfundet. Det skal understreges, at svaret på dette spørgsmål kan være motiveret af både økonomiske, sociale, sundhedsmæssige og andre forklaringer. Dertil kommer, at to ud af tre mener, at religiøse og etniske grupper i høj grad har bidraget til smittespredningen.

\section{LITTERATUR}

Cox, Daniel A. og John Halpin

2020 Fear, frustration, and faith: Americans respond to the coronavirus outbreak, American Perspectives Survey, https://www.aei.org/research-products/report/fear-frustration-and-faithamericans-respond-to-the-coronavirus-outbreak/

Cox, Daniel A. og John Halpin

2020 "Conspiracy theories, misinformation, COVID-19, and the 2020 election. Findings from the September 2020 American Perspectives Survey":

https://www.americansurveycenter.org/research/conspiracy-theories-misinformation-COVID19-and-the-2020-election/

Beckford, James A.

2003 Social Theory and Religion, Cambridge University Press.

Ferrari, Mattia

2020 "God vs. Coronavirus", (10. Marts 2020):

https://www.nytimes.com/2020/03/10/opinion/coronavirus-church-religion.html

Frederiksen, Morten ed.

2019 Usikker modernitet: danskernes værdier fra 1981 til 2017, Hans Reitzel.

Frederiksen, Morten \& Jonas Toubøl

2019 "Polarisering af danskernes tillid til hinanden" in: Morten Frederiksen ed., Usikker modernitet. Danskernes værdier fra 1981 til 2017, Hans Reitzels Forlag, 393-427.

Frederiksen, Morten

2012 "Dimensions of trust. An empirical revisit to Simmel's formal sociology of intersubjective trust", Current Sociology 60 (6), 733-750.

Furseth, Inger

2018 Religious Complexity in the Public Sphere: Comparing Nordic Countries, Palgrave Macmillian. Larsen, Christian Albrecht 
2011 "Typer af velfærdssamfund, social kapital og tillid", in: P. Hegedahl \& G.L.H. Svendsen eds., Tillid - samfundets fundament. Teorier, tolkninger, cases, Syddansk Universitetsforlag.

McGuire, Meredith B.

1998 Ritual Healing in Suburban America, Rutgers University Press.

Pew Research Center

2020a. "Most Americans say coronavirus outbreak has impacted their lives",

https://www.pewresearch.org/social-trends/2020/03/30/most-americans-say-coronavirusoutbreak-has-impacted-their-lives/

Rothstein, Bo.

2010 "Happiness and the Welfare State", Social Research 77 (2), 397-420.

Rusmann, Anna

2017 Sundhed, sikkerhed og spiritualitet. Et flermetodisk studie af trosforestillinger blandt vaccinationsmodstandere, Kandidatspeciale, Københavns Universitet.

Svendsen, Gert Tinggaard

2012 Tillid, Aarhus Universitetsforlag.

Statens Serum Institut

2020 "Status på COVID-19 smitte blandt etniske minoriteter":

https://www.ssi.dk/aktuelt/nyheder/2020/status-pa-COVID-19-smitte-blandt-etniskeminoriteter-i-danmark

Thorup, Mikkel

2014 "Sandheden vil sætte os fri':- konspirationsteori som demokratisk praksis", Slagmark Tidsskrift for idéhistorie 69, 157-172.

Ward, Charlotte, and David Voas

2011 "The emergence of conspirituality", Journal of Contemporary Religion 26 (1), 103-121.

Westengaard, Line Dam

2020 Men vi bliver også nødt til at stille spørgsmålet, om det virkelig er hele forklaringen": En undersøgelse af fremstillingen af religiøse minoriteter i Danmark under COVID-19, Kandidatspeciale, Aarhus Universitet.

Wollebæk, D., B. Enroljas, A. Fladmoe \& K. Steen-Johnsen

2020 Tillit og bekymring. Hva avgjør om folk følger koronarådene, Oslo: Institutt for samfunnsforskning.

Brian Arly Jacobsen, lektor, ph.d. Religionsvidenskab, Københavns Universitet

Lene Kühle, professor mso, ph.d. Afdeling for religionsvidenskab, Aarhus Universitet

Henrik Reintoft Christensen, lektor, ph.d. Afdeling for religionsvidenskab, Aarhus Universitet 